\title{
Genetic variability of Pantaneiro horse using RAPD-PCR markers
}

\section{Andréa Alves do Egito', Beatriz Helena Fuck 2,3 , Concepta McManus ${ }^{2}$, Samuel Rezende Paiva $^{2}$, Maria do Socorro Maués Albuquerque ${ }^{2}$, Sandra Aparecida Santos ${ }^{4}$, Urbano Gomes Pinto de Abreu ${ }^{4}$, Joaquim Augusto da Silva ${ }^{5}$, Fabiana Tavares Pires de Souza Sereno ${ }^{6}$, Arthur da Silva Mariante ${ }^{1}$}

\footnotetext{
1 Embrapa Recursos Genéticos e Biotecnologia, Caixa Postal 02372, CEP: 70770-900, Brasília-DF.

2 Universidade de Brasília, Faculdade de Agronomia e Medicina Veterinária, Caixa Postal 04508, CEP: 70910-900, Brasília-DF.

${ }^{3}$ Ministério da Defesa, Exército Brasileiro, Academia Militar das Agulhas Negras, Seção Veterinária Rodovia Presidente Dutra Km 306 CEP 27534-970, Resende-RJ.

${ }^{4}$ Embrapa Pantanal, Caixa Postal 109, CEP: 79320-900, Corumbá-MS

${ }^{5}$ Associação Brasileira dos Criadores de Cavalo Pantaneiro, Rua Joaquim Murtinho, 1070, CEP: 78175-000, Poconé-MT.

${ }^{6}$ Bolsista do CNPq. Pós-doutorado na Universidade de Brasília, Faculdade de Agronomia e Medicina Veterinária, Caixa Postas 04508, CEP: 70910-900, Brasília-DF.
}

ABSTRACT - Blood samples were collected from Pantaneiro Horses in five regions of Mato Grosso do Sul and Mato Grosso States. Arabian, Mangalarga Marchador and Thoroughbred were also included to estimate genetic distances and the existing variability among and within these breeds by RAPD-PCR (Random Amplified Polymorphic DNA - Polymerase Chain Reaction) molecular markers. From 146 primers, 13 were chosen for amplification and 44 polymorphic bands were generated. The analysis of molecular variance (AMOVA) indicated that the greatest portion of detected variability was due to differences between individuals within populations (75.47\%). Analysis of the genetic variability between pairs of populations presented higher estimates for the five Pantaneiro populations with the Arabian breed, while lowest estimates were presented by pairs formed among the Pantaneiro populations with the Mangalarga Marchador. Highest genic diversity was shown by the Pantaneiro (0.3396), which also showed highest genetic distance with the Arabian and lowest with Mangalarga Marchador breed. UPGMA dendrogram showed distinct differences between naturalized (Pantaneiro and Mangalarga Marchador) and exotic (Arabian and Thoroughbred) breeds. In the dendrogram generated by UPGMA method, the similarity matrix generated by the Jaccard coefficient showed distinction between the naturalised breeds, Pantaneiro and Mangalarga Marchador, and the exotic breeds, Árab and English Thoroughbred. Results suggest that the Pantaneiro presents a higher genetic variability than the other studied breeds and has a close relationship with the Mangalarga Marchador.

Key Words: AMOVA, Arabian, English Thoroughbred, genetic diversity, genetic resource, Mangalarga Marchador

\section{Variabilidade genética do cavalo Pantaneiro utilizando marcadores RAPD- PCR}

RESUMO - Amostras de sangue foram coletadas de cavalos Pantaneiros de cinco regiões dos estados de Mato Grosso do Sul e Mato Grosso. As raças Mangalarga Marchador, Árabe e Puro-Sangue Inglês (PSI) usando marcadores moleculares RAPDPCR (Random Amplified Polymorphic DNA - Polymerase Chain Reaction) foram incluídas no intuito de se calcular as distâncias genéticas e comparar a variabilidade genética entre e dentro de cada uma das raças. Dos 146 primers escrutinados, 13 foram escolhidos para amplificação com cada um dos indivíduos das oito populações, gerando um total de 44 bandas polimórficas. Os resultados encontrados na Análise de Variância Molecular (AMOVA) indicam que grande parte da variabilidade genética detectada se deve a diferenças entre indivíduos dentro de populações $(75,47 \%)$. Na análise da estimativa dos percentuais de variabilidade genética entre pares de populações, foram observados maiores valores para os pares formados entre as cinco populações de cavalo Pantaneiro e a raça Árabe, enquanto os menores percentuais ocorreram entre Pantaneiro e Mangalarga Marchador. Maior índice de diversidade gênica foi observado na raça Pantaneiro $(0,3396)$. No dendrograma gerado pelo método UPGMA, a partir da matriz de similaridade obtida pelo coeficiente de Jaccard, houve distinção entre as raças naturalizadas (Pantaneiro e Mangalarga Marchador) e as exóticas (Árabe e PSI). Os resultados encontrados sugerem que o Pantaneiro apresenta maior variabilidade genética que os de outras raças e está estreitamente relacionado ao Mangalarga Marchador.

Palavras-chave: AMOVA, Árabe, diversidade genética, Mangalarga Marcador, Puro-Sangue Inglês, recurso genético 


\section{Introduction}

The Pantaneiro horse is found in the Brazilian Pantanal and is well adapted to temporary local flooding conditions. It is used for transporting man in the field and leading with cattle in the region. These animals, descendents of horses brought to Brazil by the European colonizers after the discovery. They adapted and multiplied for over two hundred years and natural selection helped to define the traits found in the breed today (Sereno, 1997; Mariante \& Cavalcante, 2000).

From 1900 the breed underwent many crosses with the English-Arabian, Arabian and English Thoroughbred, to improve conformation and increase stature (Balieiro, 1971; Beck, 1985). These, associated with diseases such as Tripanosomiasis and Equine Infectious Anemia were responsible for the decrease in the population of this breed. At present, studies developed by the Brazilian Association of Pantaneiro Horse Breeders and conservation programs maintain several nuclei of the breed (Mariante \& Cavalcante, 2000; Santos, 2001).

Farm animal genetic diversity is required to meet current production needs in various environments, to allow sustained genetic improvement and to facilitate rapid adaptation to changing breeding objectives (Notter, 1999). Genetic characterization is the first step in breed conservation and may have implications for future breeding strategies (Solis et al. 2005). Cothran et al. (1998), using biochemical markers, observed that a specific population of Pantaneira horses was not influenced by recent crosses with other breeds. Nevertheless, Miserani et al. (2002) found phenotypic variations between horses from various locations within the Pantanal. Sereno (2002), using microsatellite markers, found a high degree of diversity within the Pantaneiro horse nucleus in the Nhumirim farm, of Embrapa Pantanal and concluded that the proximity to the Pura Raça Espanhola horse may indicate Iberian origin.

Random Amplified Polymorphic DNA (RAPD) analysis is a technique based on the Polymerase Chain Reaction (PCR) amplification of discrete regions of genome with short oligonucleotide primers of arbitrary sequence. The method is simple and quick to perform and no prior knowledge of the genetic make-up of the organism in question is required (Lynch \& Milligan, 1994). This technique has been used to detect genetic diversity in equines (Bailey \& Lear, 1994; Shiue et al., 1999; Apostolidis et al., 2001).

This study aimed to investigate diversity among Pantaneiro horses from five nuclei using RAPD (Williams et al., 1990; Welsh \& McClelland, 1990) markers and comparing them with other horse populations in Brazil.

\section{Material and Methods}

Five populations of Pantaneiro Horses were studied, from the following townships: Barra dos Bugres, Cuiabá and Poconé, in Mato Grosso State and Campo Grande and Corumbá, in Mato Grosso do Sul State (Table 1). These townships were chosen because of the large number of registered animals (Barra dos Bugres and Poconé) and the presence of conservation nuclei (Campo Grande, Corumbá and Cuiabá).

Animals from the Arabian, English Thoroughbred and Mangalarga Marchador were included as outgroups (Table 1), because some breeders earlier in the 20th century used the first two breeds to improve some conformation traits of the Pantaneiro (Balieiro, 1971; Beck, 1985; Santos, 1993). The Mangalarga Marchador was included to ratify the relationship observed by Cothran et al. (1998).

Genomic DNA extraction from blood cells of 352 animals was based on Miller et al. (1988) with slight modifications. A total of 146 decamer oligonucleotide primers (Operon Technologies Inc., Alameda, Calif.: A, B, E, J, K, N, S and $\mathrm{AB})$ were screened using unique samples of DNA from distinct animals and breeds. Primers were designated as useful if they yielded well-amplified, distinguishable polymorphic bands. A total of 13 primers (OP AB4, OP A4, OP A8, OP A11, OP A12, OP A16, OP A19, OP E2, OP E5, OP E19, OP N3, OP S8 and OP S18) were selected and used to amplify DNA from all individuals (Table 1).

RAPD-PCR reactions were carried out in a final volume of $13 \mu \mathrm{l}$, with $20 \mathrm{mM}$ Tris- $\mathrm{HCl}$ (pH 8.4); $50 \mathrm{mM} \mathrm{KCl} ; 3.5 \mathrm{mM}$ $\mathrm{MgCl}_{2} ; 200 \mu \mathrm{M}$ of each dNTP; $8 \%$ BSA $2.5 \mathrm{mg} / \mathrm{ml} ; 0.4 \mu \mathrm{M}$ of the arbitrary primer; $1.5 \mathrm{U}$ Taq DNA polymerase (Phoneutria

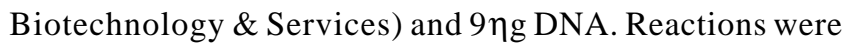
performed in a MJ Research (PTC100) thermocycler under 40 cycles of 15 second duration at $95^{\circ} \mathrm{C}, 30$ seconds at $35^{\circ} \mathrm{C}$, 1 minute at $72^{\circ} \mathrm{C}$ and at the end of the cycle 7 minutes at $72^{\circ} \mathrm{C}$, for complete extension of the amplified products.

Genetic similarity within and between individuals was estimated from RAPD data with the Jaccard Coefficient (Sneath \& Sokal, 1973), using NTSYS-pc Numerical Taxonomy and Multivariate Analysis System), version 2.0 (Exeter Software, Setauked, N.Y.). The genetic similarity indices were used to generate, using UPGMA (Sokal \& Michener, 1958), a dendrogram based on the samples used.

Nei's genetic distances (1972 and 1978) between breeds and populations were calculated using the POPGENE program (Population Genetic Analysis) version 1.31 (Yeh et al., 1999) that establishes standardized genetic distance matrices (Nei, 1972) and matrices of genetic distances 
Table 1 - Distribution of samples analysed in RAPD reactions

\begin{tabular}{|c|c|c|c|c|}
\hline \multirow[t]{2}{*}{ Population } & \multirow[t]{2}{*}{ Breed } & \multicolumn{2}{|c|}{ Number of horses } & \multirow[t]{2}{*}{ Total } \\
\hline & & Males & Females & \\
\hline Pan BB & Pantaneira - Barra dos Bugres & 14 & 28 & 42 \\
\hline Pan $\mathrm{Cu}$ & Pantaneira - Cuiabá & 22 & 26 & 48 \\
\hline Pan Po & Pantaneira - Poconé & 40 & 08 & 48 \\
\hline Pan CG & Pantaneira - Campo Grande & 06 & 25 & 31 \\
\hline Pan Co & Pantaneira - Corumbá & 21 & 27 & 48 \\
\hline A & Arabian & 10 & 35 & 45 \\
\hline MM & Mangalarga Marchador & 17 & 25 & 42 \\
\hline Thoroughbred & English Thoroughbred & 31 & 17 & 48 \\
\hline Total & & 352 & & \\
\hline
\end{tabular}

corrected for small samples (Nei, 1978).All cluster analyses were conducted using UPGMA and the resulting clusters were expressed as dendrograms. The analyses were carried out in three stages: (i) all population breeds (Pantaneiro, Arabian, Mangalarga Marchador and Thoroughbred); (ii) only Pantaneiro populations; and (iii) pairs of populations of all breeds. The POPGENE program als o generated genetic diversity indices for each breed, as a function of the means of their allelic frequencies, based on Nei (1973). Confidence values for each node of the dendrogam were estimated from 10.000 random resamplings of the data (bootstrap) using TFPGA (Tools for Population Genetics Analyses, version 1.3) (Miller, 1997).

The analysis of molecular variance (AMOVA) (Schneider et al., 2000) was used to separate the variance among and within populations using the ARLEQUIN program. Although this test was not originally designed for analysis of RAPD data, it has been used in other similar studies (Jaggi et al., 2000; Lougheed et al., 2000; Tansley \& Brown, 2000).

\section{Results and Discussion}

Of 146 primers studied, $60(41.1 \%)$ yielded polymorphic bands and 47 yielded monomorphic bands (32.19\%), as well as $39(26.71 \%)$ bands that were poorly amplified or did not amplify. Primers were selected based on number of polymorphic bands and amplification quality. A total of 44 polymorphic bands were considered with an average 3.38 bands/primer. Bailey \& Lear (1994) studying Arabian and Thoroughbred breeds found an average of 3.6 polymorphic bands/primer in a RAPD assay. Martins (1996), studying three Brazilian breeds (Lavradeiro, Crioulo and Campolina) found 2.9 bands/primer, using 29 markers. Apostolidis (2001) found 10.2 bands/primer and 51 polymorphic bands in Greek horses (Thessalian, Skyros Pony, Pinia, Cretan and Andravida). This author did not find any specific markers, while Bayley \& Lear (1994) and Martins (1996) did find breed-specific RAPD markers for Arabian/Thoroughbred and Lavradeiro horses, respectively.

The AMOVA analysis showed that the greatest part of the total genetic variation $(75.47 \%)$ was due to differences between individuals within breeds and that between breeds variance accounted for $24.53 \%$. Using only the Pantaneiro, populations accounted for $16.26 \%$ of the total variation and with pairs of populations this variation accounted for between $24.54 \%$ (Poconé and Corumbá populations) and $11.10 \%$ (Poconé and Barra do Bugres populations) (Table 2). Similar results were found in native cattle breeds using RAPD markers (Serrano, 2001; Spritze 2003).

When all breeds were considered, greatest differences were observed between the Pantaneiro and Arabian, while comparisons with the Thoroughbred and Mangalarga Marchador showed fewer differences (Table 2). According to Cothran et al. (1998) the greater similarity between the Pantaneiro and Mangalarga Marchador breeds, when compared with Thoroughbred and Arabian, shows that all the Brazilian breeds studied are closely related to each other. Comparing Pantaneiro populations with Mangalarga Marchador, the Mangalarga Marchador/Poconé pair showed a high level of variability, Mangalarga Marchador/Corumbá and Mangalarga Marchador/Campo Grande pair comparison showed lower variability than most comparisons within the Pantaneiro. When the Pantaneiro was considered a single population, paired comparisons showed: $25.91 \%$ between breed variability for Pantaneiro/Arabian, $12.84 \%$ for Pantaneiro/Mangalarga Marchador and $20.01 \%$ for Pantaneiro/Thoroughbred.

The greatest index of genetic diversity was observed when the five populations were considered as one (Table 3), but when considered separately each Pantaneiro population showed lower diversity index than that of the breed. According to Cothran et al. (1998) individual and population estimates of genetic variation of the Pantaneiro indicate that variation levels are normal for horses and 
Table 2 - Estimates of genetic variability percentages due to differences between populations by AMOVA ${ }^{1}$

\begin{tabular}{lcccccc}
\hline Item & Pan BB & Pan CG & Pan Co & Pan Cu & Pan Po & A \\
\hline Pan CG & 21.81 & & & & & \\
Pan Co & 22.89 & 23.72 & & & & \\
Pan Cu & 20.04 & 22.76 & 16.43 & & & \\
Pan Po & 11.10 & 22.38 & 24.54 & 17.71 & & \\
A & 42.07 & 35.52 & 36.83 & 27.91 & 38.99 & 24.23 \\
MM & 25.78 & 17.43 & 11.44 & 20.41 & 31.94 & 2.62 \\
Thoroughbred & 28.82 & 25.64 & 25.39 & 27.15 & 27.44 & 23.17 \\
\hline
\end{tabular}

${ }^{1}$ Abbreviations - see Table 1.

there is no indication of inbreeding. The populations from Campo Grande and Cuiabá had the highest values for the genic diversity index, while the lowest was for those from the Barra do Bugres and Poconé, which had lower indices than the Arabian and Thoroughbred breeds. In general, greater variability between pairs of populations was accompanied by greater distances between the same pairs, for example Poconé/Corumbá, Campo Grande/Corumbá and Campo Grande/Cuiabá. The Barra do Bugres/Poconé pair showed less variability and closer distance. Exchange of germplasm should preferentially be carried out between nuclei with greater distances and high variability to maintain genetic variation within the breed. The exchange of germplasm between Barra do Bugres and Poconé, Corumbá and Cuiabá or Cuiabá and Poconé may compromise variation levels as there are lower estimated values between these populations than within the breed as a whole. Townships geographically more distant donot present highest distances and genetic variability $(\mathrm{P}<0.05)$. This may be due to exchange of animals between different studs.

The results for the AMOVA and genetic distances calculated using Nei (1972) show a direct relationship between the Pantaneiro and Mangalarga Marchador breeds, for each population individually as well as the five populations considered together. The population from Corumbá showed a lower distance measure from the Mangalarga Marchador than the other populations in the same breed. Similar results were found by Cothran et al. (1998) using samples from Corumbá, Campo Grande and Rio Verde who showed that three populations formed acluster with the Mangalarga and a largercluster with Mangalarga Marchador and Campolina. These findings are in agreement with the history of the origin of the naturalized Brazilian breeds, which have common ancestor: animals introduced by European colonizers.

As can be seen in Table 3, and in agreement with Cothran et al. (1998), the Mangalarga Marchador showed a lower genic diversity index than the Pantaneiro. The animals from Barra dos Bugres, Poconé and Corumbá, showed lower
Table 3 - Genic diversity for populations ( ${ }^{*} h$ ), from allelic frequencies using Nei (1973)/POPGENE

\begin{tabular}{lcc}
\hline Population & $\mathrm{N}^{\circ}$ of animals & $(* \mathrm{~h})$ \\
\hline Pantaneiro & 217 & 0.3396 \\
Pantaneiro - Barra dos Bugres & 42 & 0.2365 \\
Pantaneiro - Campo Grande & 31 & 0.2973 \\
Pantaneiro - Corumbá & 48 & 0.2697 \\
Pantaneiro - Cuiabá & 48 & 0.2936 \\
Pantaneiro - Poconé & 48 & 0.2500 \\
Arabian & 45 & 0.2814 \\
Mangalarga Marchador & 42 & 0.2710 \\
Thoroughbred & 48 & 0.2617 \\
\hline
\end{tabular}

diversity indices than the Mangalarga Marchador, possibly because of the intense use of a few stallions (such as the stallion Taiamã in Poconé). This animal is held as a prime example of the breed and is widely used in the region. This single stallion sired $15 \%$ of the animals registered by the ABCCP.

Although remote, the possibility of crossbreeding between the Pantaneiro and Mangalarga Marchador must be considered to justify the relationship between them. Since Campo Grande and Cuiabá are two large urban centers situated outside the Pantanal Matogrossense, this allowed greater interaction with Mangalarga Marchador breeders, a breed widely used in Brazil. Nevertheless it is important to note that the samples studied here came from Pantaneiro breeders, who carefully control their herds for the last 20 years or so. The equine species has a long generation interval, about 12 years, which means this control only exists for about 2 generations.

The genetic distances expresses the degree of divergence between populations. Higher valueswere found for the pairs formed between each of the five Pantaneiro populations and the Arabian. Smaller, but still high values, were found for distances between Pantaneiro and Thoroughbred populations, which may mean that past crossbreeding no longer has much influence on the Pantaneiro breed. These results were expected as they represent pairs of comparisons with distinct breeds but do 
not agree with Sereno (2002) or Cothran et al. (1998) who found greater distances for the Pantaneiro/Thoroughbred pair than the Pantaneiro/Arabian. In this study only the Pantaneiro from Cuiabá had a higher distance compared with the Thoroughbred than the Arab. The present study used 217 samples from a greater number of subpopulations, although used the same population studied by Sereno (2002) (Corumbá), and a greater part of those studied by Cothran et al. (1998), Campo Grande and Corumbá. Therefore the divergence in results may be caused by genetic variability introduced in the subpopulations of Barra dos Bugres, Cuiabá and Poconé (not previously studied).

Table 4 shows standardized and corrected genetic distances due to Nei (1972 and 1978, respectively). The corrected distances were lower than the standardized, but proportionally no differences between the relationships were noted. Highest genetic distances were observed between the five Pantaneiro populations and the Arabian, followed by Pantaneiro and Thoroughbred. The lowest value for the regular genetic distance (below diagonal) was between the Corumbá/Mangalarga Marchador pair. The Barra do Bugres/Poconé, Barra do Bugres/Corumbá and Barra do Bugres/Cuiabá pairs also showed low values. When only the five Pantaneiro populations were considered (above diagonal), the greatest distances were between Corumbá/ Poconé, Corumbá/Campo Grande and Campo Grande/Cuiabá.

The Thoroughbred had the lowest genic diversity index. This is in agreement with the result found by Bowling \& Clark (1985), who studied Thoroughbred, Arabian, Standardbred, Morgan, Quarter Horse, Paso Fino and Peruvian Paso. They observed a lower biochemical marker variation in Thoroughbred and concluded that this was due to a Stud Book that has been closed for more than 200 years, as well as intense selection for a single trait: speed in flat races.

The Pantaneiro populations grouped together (Figure 1) in a single cluster. The Mangalarga Marchador was also included in this cluster and was grouped with the Corumbá Pantaneiro, which was the only node with a confidence level higher than $70 \%$.

The dendrogram in Figure 1 is in agreement with that found by Cothran et al. (1998) and Sereno (2002), where a distinct separation between naturalized (Pantaneiro and Mangalarga Marchador) and exotic breeds (Arab and Thoroughbred) is noted. The Pantaneiros from Corumbá were paired with the Mangalarga Marchador, in agreement with the AMOVA andgenetic distances, which indicated a close relationship between these two populations.

The Jaccard similarity coefficient (Figure 2) with all animals analyzed individually, showed a clear distinction between the naturalized (Pantaneiro and Mangalarga Marchador) and exotic breeds (Arab and Thoroughbred). Ninety seven percent of the Pantaneiro horses were in a single cluster and generally, examining sub-clusters, at least $60 \%$ of the horses from a single region were grouped in each individual sub-cluster. The exceptions were the horses from Corumbá and Cuiabá which had 52 and 65\% respectively, of the samples in clusters of other Pantaneiro

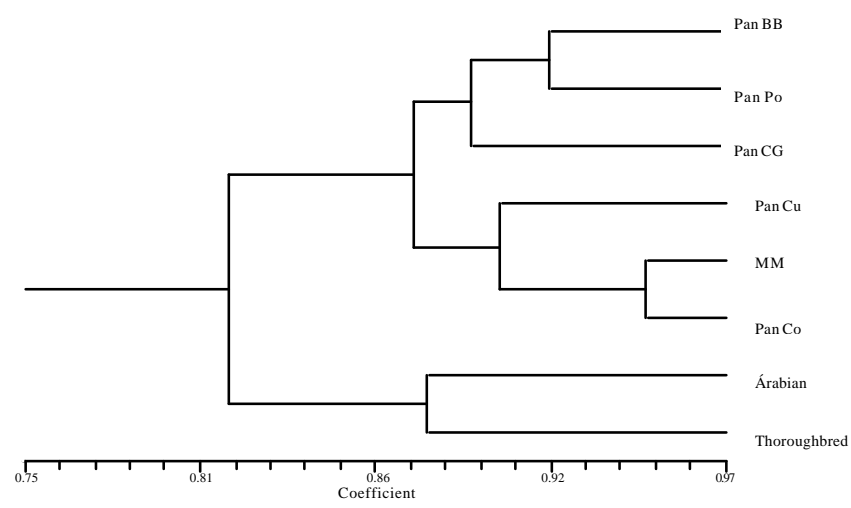

Figure 1 - Dendrogram from UPGMA method for genetic identity using Nei (1972) ${ }^{1}$.

${ }^{1}$ Abbreviations - see Table 1.

Table 4 - Genetic distances among eight populations of horses using Nei (1972, below diagonal and 1978 above diagonal), program POPGENE ${ }^{1}$

\begin{tabular}{|c|c|c|c|c|c|c|c|c|}
\hline & PanBB & PanCG & PanCO & PanCU & PanPO & A & MM & Thoroughbred \\
\hline PanBB & $* * * *$ & 0.1047 & 0.0864 & 0.0917 & 0.0852 & 0.2338 & 0.1151 & 0.2128 \\
\hline PanCG & 0.1101 & $* * * *$ & 0.1509 & 0.1484 & 0.1168 & 0.2476 & 0.1365 & 0.2192 \\
\hline PanCO & 0.0901 & 0.1564 & $* * * *$ & 0.0975 & 0.1550 & 0.2238 & 0.0526 & 0.1734 \\
\hline PanCU & 0.0957 & 0.1543 & 0.1017 & $* * * *$ & 0.1221 & 0.1637 & 0.1064 & 0.1813 \\
\hline PanPO & 0.0890 & 0.1225 & 0.1590 & 0.1264 & $* * * *$ & 0.2274 & 0.1857 & 0.1897 \\
\hline A & 0.2380 & 0.2536 & 0.2281 & 0.1683 & 0.2319 & $* * * *$ & 0.1975 & 0.1285 \\
\hline $\mathrm{MM}$ & 0.1189 & 0.1422 & 0.0566 & 0.1108 & 0.1899 & 0.2019 & $* * * *$ & 0.1517 \\
\hline Thoroughbred & 0.2164 & 0.2245 & 0.1772 & 0.1854 & 0.1936 & 0.1327 & 0.1555 & $* * * *$ \\
\hline
\end{tabular}

${ }^{1}$ Abbreviations - see Table 1.

All values were significant $(P<0.05)$. 


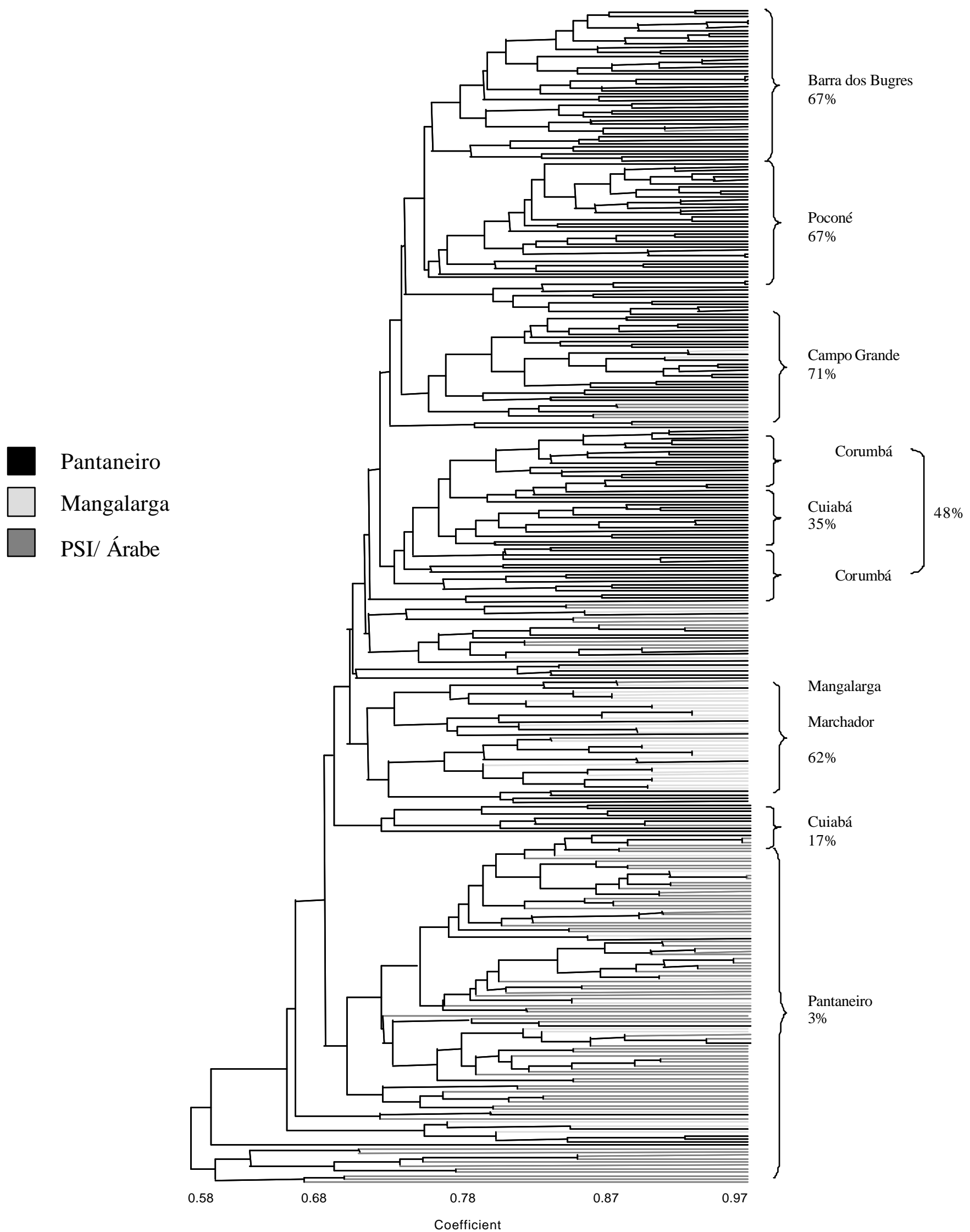

Figure 2 - Dendrogram generated by UPGMA method for the Jaccard coefficient for RAPD data from 352 animals and 44 polymorphic bands. Percentages represent the percentage of the total number of animals from a specific region or breed within that region of the dendrogram. 
and Mangalarga Marchador populations. Also, 35\% of the individuals from Cuiabá and $48 \%$ from Corumbá, were found in the same cluster. The Mangalarga Marchador had $76 \%$ of its individuals in the large cluster of the Pantaneiro breed. The populations of Pantaneiro, closest to Mangalarga Marchador, independent of the analysis were those from Corumbá, Campo Grande and Cuiabá.

The presence of individuals from different populations in the same cluster generated similarity matrix (Jaccard coefficient of similarity) is probably due to the interchange of animals between different farms. This is the case for example of the animals from Corumbá, which use two stallions from Cuiabá. Another important factor is the number of markers used here; maybe an increase in the number of bands would promote a greater distinction between groups and individuals.

The results of the AMOVA and by genetic distances (Nei, 1972) indicate that the Arabian and Thoroughbred breeds are more similar within themselves than with the Pantaneiro and Mangalarga Marchador. Although well dispersed throughout the world and closed stud books the Thoroughbred and Arab have similar origins as Arabs were the foundation of the Thoroughbred (Bowling \& Clark, 1985).

\section{Conclusions}

Data generated by this RAPD study are useful in estimating distances between and within breeds and might help futures programs of management and conservation. Of the breeds studied here, the Pantaniero had the highest genetic variability. Results indicate that this breed is close to the Mangalarga Marchador, in agreement with known breed history which indicates a common ancestor for both and crossbreeding using Arabian and Thoroughbred stallions. Although there was not complete isolation between the populations examined, genetic differences between regions were observed indicating that a crossbreeding strategy is required to maintain genetic diversity and avoid inbreeding within this population.

\section{Acknowledgements}

To CNPq for scholarship for the $3^{\text {rd }}$ author.

\section{Literature Cited}

APOSTOLIDIS, A.P.; MAMURIS, Z.; KARKAVELIA, E.; ALIFAKIOTIS, T. Comparison of Greek breeds of horses using RAPD markers. Journal of Animal Breeding and Genetics, v. 118 , p. 47-56, 2001.
BAILEY, E.; LEAR, T.L. Comparison of Thoroughbred and Arabian horses using RAPD markers. Animal Genetics, v.25, p.105108, 1994 (suppl 1).

BALIEIRO, E.S. Subsídio ao estudo do cavalo Pantaneiro. São Paulo. Anuário Comissão Coordenadora da Criação do Cavalo Nacional. Brasília: Ministério da Agricultura, 1971. p.59-65.

BECK, S.L. Equinos: raças, manejo e equitação. 2.ed. São Paulo: Editora dos Criadores, 1985. 479p.

BOWLING, A.T.; CLARK, R.S. Blood group and protein polymorphism gene frequencies for seven breeds of horses in the United States. Animal Blood Groups and Biochemical Genetics (presently Animal Genetics), v.16, p.93-108, 1985.

COTHRAN, E.G.; SANTOS, S.A.; MAZZA, M.C.M. et al. Genetics of the Pantaneiro horse of the Pantanal region of Brazil. Genetics and Molecular Biology, v.21, n.3, p.343-349, 1998.

JAGGI, C.; WIRTH, T.; BAUR, B. Genetic variability in subpopulations of the Asp Viper (Vispera aspis) in Swiss Jura Mountains: implications for a conservation strategy. Biological Conservation, v.94, p.69-77, 2000.

LYNCH, M.; MILLIGAN, B.G. Analysis of population genetic structure with RAPD markers. Molecular Ecology, v.3, n.2, p.91-99, 1994.

LOUGHEED, S.C.; GIBBS, K.A; WEATHERHEAD, P. J. A comparison of RAPD versus microsatellite NDA markers in population studies of the Massasauga Rattlesnake. Journal of Heredity, v.91, p.458-463, 2000.

MARIANTE, A.S.; CAVALCANTE, N. Animais do descobrimento: raças domésticas da história do Brasil. Brasília: EmbrapaCenargen, 2000. 232p.

MARTINS, V.B. Técnica de diagnóstico com marcadores RAPD para uso e preservação de germoplasma eqüino. Brasília: Universidade de Brasília, 1996. 44p. Dissertação (Mestrado em Saúde) - Universidade de Brasília, 1996.

MILLER, M.P. [1997]. Tools for population genetics analyses (TFPGA): a Windows program for the analysis of allozyme and molecular population genetic data. Disponível em: <http:// herb.bio.nau.edul miller/tfpga.htm>. Acesso em: 10/12/04.

MILLER, S.A.; DYKES, D.D.; POLESKY, H.F. A simple salting out procedure for extracting DNA from human nucleated cells. Nucleic Acids Research, v.16, p.1215, 1988.

MISERANI, M.G.; McMANUS, C.; SANTOS, S.A. et al. Avaliação dos fatores que influem nas medidas lineares do cavalo Pantaneiro. Revista Brasileira de Zootecnia, v.31, n.1, p.335-341, 2002.

NEI, M. Analysis of gene diversity in subdivided populations. Proceedings of the National Academy of Science of United States of America, v.70, p.3321-3323, 1973.

NEI, M. Estimation of average heterozygosity and genetic distance from a small number of individuals. Genetics, v.89, p.583590, 1978.

NEI, M. Genetic distance between populations. American Naturalist, v.106, p.238-292, 1972.

NOTTER, D.R. The importance of genetic diversity in livestock populations of the future. Journal of Animal Science, v.77, p.61-69, 1999 .

SANTOS, S.A. Avaliação e conservação do cavalo Pantaneiro no Pantanal Mato-grossense. In: REUNIÃO ANUAL DA SOCIEDADE BRASILEIRA DE ZOOTECNIA, 30., 1993, Rio de Janeiro. Anais... Rio de Janeiro: Sociedade Brasileira de Zootecnia, 1993. p.287-312.

SANTOS, S.A.; McMANUS, C.M.; MARIANTE, A.S. et al. A review of Conservation and Management of the Pantaneiro horse in the Brazilian Pantanal. Animal Genetic Resources Information, v.31, p.75-86, 2001.

SCHNEIDER, S., ROESSLI, D.; EXCOFFIER, L. Arlequin version 2000: A software for population genetics data analysis. Geneva: University of Geneva, 2000. 111p.

SERENO, J.R.B.; SANTOS, S.A.; ZUCCARI, C.E.S.N.; MAZZA, M.C.M. Establishment of a breeding season and evaluation of 
the reproductive performance of the Pantaneiro hose in Mato Grosso do Sul, Brazil. Aninal Genetic Resources Information, v.21, p.43-48, 1997.

SERENO, F.T.P.S. Caracterización genética del caballo Pantaneiro. Córdoba: Universidad de Córdoba, 2002. 126p. Tesis (Doctoral in Genetica Animal) - Universidad de Córdoba, 2002.

SERRANO, G.M.S.; EGITO, A.A.; McMANUS, C.M.; MARIANTE, A.S. Genetic diversity and population structure of Brazilian native bovine breeds based on RAPD markers. Pesquisa Agropecuária Brasileira, v.39, p.543-549, 2004.

SHIUE, Y.L.; BICKEL, L.A.; CAETANO, A.R. et al. A synteny map of the horse genome comprised of 240 microsatellite and RAPD markers. Animal Genetics, v.30, p.1-9, 1999.

SNEATH, P.H.A.; SOKAL, R.R. Numerical taxonomy: the principles and practice of numerical classification. San Francisco: W. H. Freeman, 1973. 573p.

SOKAL, R.R.; MICHENER., C.D. A statistical method for evaluating systematic relationships. University Kansas Science Bulletin, v.38, n.22, p.1409-1438, 1958.

SOLIS, A.; JUGO, B.M.; MÉRIAUX, J.C. et al. Genetic diversity within and among four south European native horse breeds base don microsatellite DNA analysis: implications for conservation. Journal Heredity, v.96, n.6, p.670-678, 2005.
SPRITZE, A.L.; EGITO, A.A.; MARIANTE, A.S.; McMANUS, C.M. Caracterização genética da raça bovina Crioulo Lageano usando marcadores moleculares RAPD. Pesquisa Agropecuária Brasileira, v.38, n.10, p.1157-1164, 2003.

TANSLEY, S.A.; BROWN, C.R. RAPD variation in the rare and endangered (Proteaceae): implications for their conservation. Biological Conservation, v.95, p.39-48, 2000.

WELSH, J., MCCLELLAND, M. Fingerprinting genomes using PCR with arbitrary primers. Nucleic Acids Research, v.18, p.7213-7218, 1990.

WILLIAMS, J.G.K.; KUBELIK, A.R.; LIVAK, K.J. et al. DNA polymorphisms amplified by arbitrary primers are useful as genetics markers. Nucleic Acids Research, v.18, p.65316535, 1990.

YEH, F. C.; YANG, R.; BOYLE, T.POPGENE Microsoft Windowbased freeware for population genetic analysis: version 1.3: manual. Edmonton: University of Alberta, 1999. 29p. 